Original article

\title{
Evidences on overweight of regular blood donors in a center of Southern Italy
}

\author{
Maria Vasco $^{\mathrm{a}, *, 1}$, Dario Costa ${ }^{\mathrm{a}, 1}$, Michele Scognamiglio ${ }^{\mathrm{a}}$, Giuseppe Signoriello ${ }^{\mathrm{b}}$, Roberto Alfano ${ }^{\mathrm{c}}$, \\ Karin Magnussen ${ }^{\mathrm{d}}$, Claudio Napoli ${ }^{\mathrm{a}, \mathrm{c}}$ \\ ${ }^{a}$ U.O.C. Division of Clinical Immunology, Immunohematology, Transfusion Medicine and Transplant Immunology, Department of Internal Medicine and Specialistics, \\ University of Campania "Luigi Vanvitelli", Naples, Italy \\ ${ }^{\mathrm{b}}$ Department of Mental Health and Preventive Medicine, Chair of Statistics, University of Campania "Luigi Vanvitelli", Naples, Italy \\ c Department of Medical, Surgical, Neurological, Metabolic and Geriatric Sciences, University of Campania “Luigi Vanvitelli", Naples, Italy \\ ${ }^{\mathrm{d}}$ Department of Blood Centre and Medical Biochemistry, Innlandet Hospital Trust, Lillehammer, Norway
}

A R T I C L E I N F O

\section{Keywords:}

Nutritional habits

Questionnaire

Blood donors

Well-being

Overweight

\begin{abstract}
A B S T R A C T
Objective: Smoking, unhealthy diet and obesity, sedentary behavior and inability to maintain adequate exercise have significant consequences for several chronic disorders. Blood centers can play a public health role in obesity surveillance and interventions. The purpose study was to evaluate the health status of the blood donors by monitoring the nutritional habits and lifestyle.

Methods: A descriptive cross-sectional face-to-face questionnaire was developed. It included a 41 item dietary assessment, reporting semi-quantitative food frequency, dietary behavior and questions on self-rated health status. Donors were regular repeat blood donors, eligible to donate.

Results: Of the 2468 blood donors enrolled between July 2017 and January 2018, 1390 were repeat donors. Only 205 agreed to respond to the questionnaire. Data showed that donors followed mainly a Mediterranean diet and had more awareness to lifestyle, women more than men, in comparison with general population. The prevalence of overweight was found $50.7 \%$ in men and $16.9 \%$ in women.

Conclusions: Overweight and obesity are common among regular blood donors and it is more frequent in men than women. The female blood donors seem to be characterized by better knowledge on the relationship between lifestyle and health, and by a better "putting into practice" of the information possessed.
\end{abstract}

\section{Introduction}

The quality of life, self-reported by the patient, related to health and adequate quali-quantitative nutrition, are becoming necessary and relevant in the field of nutrition. ${ }^{1-3}$ A regular monitoring of dietary aspects and lifestyle, with the aim of correcting the inexpedient behavior could provide an essential improvement in the health. ${ }^{4-6}$ Smoking, unhealthy diet and obesity, sedentary behavior and inability to maintain adequate exercise represent the most important risk factor associated to several chronic disorders, including cardiovascular diseases, diabetes, dyslipidemia and cancer. ${ }^{7-10}$ The situation is worrying considering data from World Health Organization (http://www.who.int/ news-room/fact-sheets/detail/obesity-and-overweight) with more than 1.9 billion adults (18 years and older) overweight and over 650 million obese, showing an increase of obesity rate of three fold since 1975 . To adequately describe the magnitude of the phenomenon it was necessary to introduce the term of globesity, indicating a considerable health problem and of health public due to the "global and growing epidemic of overweight and obesity" which threatens the world population health. ${ }^{11,12}$ In Italy, data demonstrated that overweight and obesity is increasing with 3 adults of 10 overweight and 1 of 10 obese in 2017. In particular, data showed a gradient from North to South of Italy with a higher frequency of overweight and obesity in the South. ${ }^{13}$

Health should not be considered only as the absence of disease but must ensure full physical, mental, social and occupational satisfaction. ${ }^{14,15}$ However, only few studies on the psychological well-being related to nutritional studies have been reported. ${ }^{16}$

Blood Center data could provide an excellent opportunity for dissecting the lifestyle assessment of blood donors. So, in this study we administered a questionnaire to blood donors in order to investigate

\footnotetext{
* Corresponding author.

E-mail addresses: mariavasco@libero.it, maria.vasco@policliniconapoli.it (M. Vasco).

${ }^{1}$ Authors contributed equally to this work.
} 
their physical activity, dietary intake, smoking, alcohol consumption and health-related life satisfaction. The purpose of this study was to evaluate the health status of the blood donors by monitoring the nutritional status and lifestyle.

\section{Patients and methods}

\subsection{Participants}

The survey was conducted at the UOC of Clinical Immunology, Immunohematology and Transfusion Medicine of the University of Campania "L. Vanvitelli", which usually investigates blood donors. ${ }^{17-19}$ We comprised data of all successful blood donations from July 2017 to January 2018. We selected only blood donors who had made at least 3 donations in the last 2 years (repeat donors). During the study period, for donors who gave more than one donation, data were recorded only at their first donation.

Donors that didn't meet the eligibility criteria for blood donation, according to national guidelines, were not included in the study [http://www.centronazionalesangue.it/sites/default/files/it_

standards_transf_med.pdf]. Whole blood donations, as well as red blood cell and platelet apheresis were included. Height and weight were measured and recorded at the time of donation by blood centre personnel. From every donor written consent was obtained to provide blood samples for research purposes. Ethics approval was provided by the University of "Luigi Vanvitelli" Human Research Ethics Committee (n. 538618).

\subsection{Questionnaire}

As reported by Rigas et al., ${ }^{20}$ we developed a descriptive crosssectional face-to-face questionnaire with 41 questions for lifestyle assessment. There were questions on blood donors' demographics covering the age, gender, education, social class and occupation. The second part included the questions on the blood donors' nutritional habits and lifestyle, including 13 semi-quantitative food frequency questions and 19 dietary behavior questions. They were also asked about their physical activity, smoking, and alcohol consumption. Also the frequency and intensity of physical activity were assessed. Selfrated health status was also reported (participants were asked "In general, would you say that your health is excellent, very good, good, fair, or poor?"); the number of days in the last month in which the respondent did not feel well for physical reasons, the number of days when he/she was not feeling well for mental and/or psychological reasons and the number of days in which he/she had limitations in habitual activities.

\subsection{Statistical analysis}

Body mass index (BMI) was calculated as weight (in kilograms) divided by the square of height (in meters). Normal weight was established with $\mathrm{BMI}<25 \mathrm{~kg} / \mathrm{m}^{2}$, overweight with a $\mathrm{BMI} \geq 25$ and $<$ $30 \mathrm{~kg} / \mathrm{m}^{2}$, and obesity with BMI $\geq 30 \mathrm{~kg} / \mathrm{m}^{2}$. Obesity prevalence was standardized by sex. Finally, adjusted odds ratios (aOR) for obesity and 95\% confidence intervals were calculated using multivariable logistic regression. The relationship between perception of the dichotomized health status (good/very good) and the independent variables were analyzed by a multiple logistic regression model. For independent samples and quantitative variables were made descriptive statistics and univariate comparisons by t-student test, and for qualitative variables by chi-square test. The significance is set at $p<0.05$.

\section{Results}

We analyzed data on donors who gave any type of blood donation between July 1, 2017 and January 31, 2018. During this time 2468

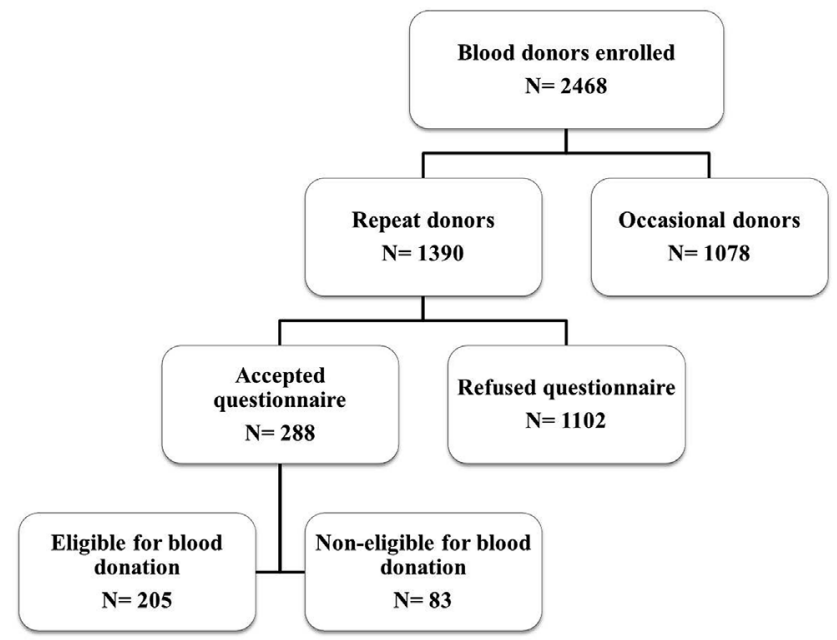

Fig. 1. Flow chart of blood donors for the assessment on nutritional habits and lifestyle.

donors were enrolled at blood center, 1390 were regular repeat donors and 1078 were occasional donors (Fig. 1). The questionnaire was proposed to all regular repeat blood donors. 1102 did not wish or chose not to respond at survey for several reasons (i.e. lack of time or privacy) and 288 accepted, of which 83 were deferred from blood donation and were excluded from the analysis. Among the 205 included participants $68.3 \%(\mathrm{n}=140)$ were male, age ranged from 19 to 61 years with a mean age of $39.8 \pm 11.1$ SD and $31.7 \%(n=65)$ were female age ranged from 20 to 62 years with a mean age of $37.7 \pm 11.0 \mathrm{SD}$. In Table 1 we reported socio-demographics variables of interviewees. Blood donors were characterized by a high level of education and women had a higher degree than men (42.9\% vs 44.6\%). It was also asked how often the interviewees practiced activities organized sports such as running, walking, football, gym, swimming pool, or other. It turned out that $58.0 \%$ of them did not practice any sport while $42.4 \%$ did it $(47.7 \%$ women $v$ s $39.9 \%$ men). The favorite sport was running (12.7\%), followed by the gym (10.7\%), football (6.3\%), swimming pool (5.9\%), walk (5.9\%) and only $0.5 \%$ cycling. Those who practiced sport every day were $17.4 \%$, from one to three times a week made up $61.6 \%$ and $20.9 \%$ practiced sport only on weekends. Most of them $(83.7 \%)$ practiced sport for an hour, $6.9 \%$ less than $1 \mathrm{~h}$ and $9.3 \%$ more than $2 \mathrm{~h}$.

Interestingly, a percentage of $90.7 \%$ of respondents assessed to follow a Mediterranean diet (Table 2). Almost all (97.1\%) declared that they usually consume breakfast, preferring a lighter one. Lunch was usually consumed by almost all respondents (94.6\%), eating preferentially vegetables (39.7\%). The dinner consisted of meat/fish with vegetables and fruit (73.2\%), followed by $23.9 \%$ which had a complete meal (from pasta to dessert). The alcohol consumption was also investigated and $33.8 \%$ (mainly men, 39.3\%) that drank alcoholic beverages, preferring wine $(51.4 \%)$ or beer $(47.1 \%)$ and only $1.4 \%$ drinking strong alcoholic beverages.

In Fig. 2 the difference of B.M.I. between men and women were reported that resulted significant $(p<0.001)$. Data showed that most women had a normal weight $(76.9 \%)$, whereas half the men resulted prevalently overweight (50.7\%). No significant correlation was found between the biochemical and hematological parameters and BMI (data not showed).

In Table 3 we have summarized the answers about perception of own health state. Two questions were asked to blood donors regarding the perception of own health state ("In general, would you say that your health is very good/good/bad/very bad?") and the number of days (in the last month) in which they had health problems. Our survey showed that $84.4 \%$ of the participants evaluated their health as "good", without gender difference (men, $86.4 \%$ vs women, $80.0 \%$ ). Besides, $14.6 \%$ 
Table 1

Socio-demographic characteristics of blood donors.

\begin{tabular}{|c|c|c|c|c|c|c|c|c|}
\hline \multirow[t]{2}{*}{ Characteristics } & \multirow[t]{2}{*}{ Answers } & \multicolumn{2}{|c|}{ Male } & \multicolumn{2}{|c|}{ Female } & \multicolumn{2}{|c|}{ Total } & \multirow[t]{2}{*}{ p-value } \\
\hline & & $\mathrm{n}$ & $\%$ & $\mathrm{n}$ & $\%$ & $\mathrm{n}$ & $\%$ & \\
\hline \multirow[t]{3}{*}{ Age } & $62-47$ & 35 & 25.0 & 17 & 26.2 & 52 & 25.4 & 0.580 \\
\hline & $46-32$ & 41 & 29.3 & 23 & 35.4 & 64 & 31.2 & \\
\hline & $31-18$ & 64 & 45.7 & 25 & 38.5 & 89 & 43.4 & \\
\hline \multirow[t]{4}{*}{ Education level } & Master's degree & 60 & $42.9 \%$ & 29 & $44.6 \%$ & 89 & $43.4 \%$ & 0.455 \\
\hline & High school diploma & 57 & $40.7 \%$ & 23 & $35.4 \%$ & 80 & $39.0 \%$ & \\
\hline & Lower secondary school certificate & 23 & $16.4 \%$ & 12 & $18.5 \%$ & 35 & $17.1 \%$ & \\
\hline & Elementary license & 0 & $0.0 \%$ & 1 & $1.5 \%$ & 1 & $0.5 \%$ & \\
\hline \multirow[t]{4}{*}{ Working situation } & Self-employed & 10 & $7.1 \%$ & 2 & $3.1 \%$ & 12 & $5.9 \%$ & 0.126 \\
\hline & Employee & 58 & $41.4 \%$ & 20 & $30.8 \%$ & 78 & $38.0 \%$ & \\
\hline & Worker & 24 & $17.1 \%$ & 10 & $15.4 \%$ & 34 & $16.6 \%$ & \\
\hline & Student. unemployed. housewife & 48 & $34.3 \%$ & 33 & $50.8 \%$ & 81 & $39.5 \%$ & \\
\hline \multirow[t]{4}{*}{ "How do you go to work?" } & On foot & 35 & $26.1 \%$ & 28 & $47.5 \%$ & 63 & $32.6 \%$ & $0.031 *$ \\
\hline & By bicycle & 6 & $4.5 \%$ & 0 & $0.0 \%$ & 6 & $3.1 \%$ & \\
\hline & Public transport & 49 & $36.6 \%$ & 18 & $30.5 \%$ & 67 & $34.7 \%$ & \\
\hline & Car/motorbike & 43 & $32.1 \%$ & 13 & $22.0 \%$ & 56 & $29.0 \%$ & \\
\hline \multirow[t]{3}{*}{ Job type } & Sedentary & 100 & $73.5 \%$ & 41 & $66.1 \%$ & 141 & $71.2 \%$ & 0.294 \\
\hline & Mild/moderate physical activity & 34 & $25.0 \%$ & 21 & $33.9 \%$ & 55 & $27.8 \%$ & \\
\hline & Vigorous physical activity & 2 & $1.5 \%$ & 0 & $0.0 \%$ & 2 & $1.0 \%$ & \\
\hline \multirow[t]{2}{*}{ Sport } & Yes & 55 & $39.9 \%$ & 31 & $47.7 \%$ & 86 & $42.4 \%$ & 0.292 \\
\hline & No & 85 & $60.7 \%$ & 34 & $52.3 \%$ & 119 & $58.0 \%$ & \\
\hline \multirow[t]{6}{*}{ Sport type } & Footing & 21 & $15.0 \%$ & 5 & $7.7 \%$ & 26 & $12.7 \%$ & $0.001^{*}$ \\
\hline & Walk & 2 & $1.4 \%$ & 10 & $15.4 \%$ & 12 & $5.9 \%$ & \\
\hline & Football & 13 & $9.3 \%$ & 0 & $0.0 \%$ & 13 & $6.3 \%$ & \\
\hline & Gymnastic & 11 & $7.9 \%$ & 11 & $16.9 \%$ & 22 & $10.7 \%$ & \\
\hline & Swimming pool & 7 & $5.0 \%$ & 5 & $7.7 \%$ & 12 & $5.9 \%$ & \\
\hline & Bicycle & 1 & $0.7 \%$ & 0 & $0.0 \%$ & 1 & $0.5 \%$ & \\
\hline \multirow[t]{3}{*}{ Number of days sport } & Every day & 11 & $20.0 \%$ & 4 & $12.9 \%$ & 15 & $17.4 \%$ & $0.016^{*}$ \\
\hline & Some day ( $2 / 3$ days) & 28 & $50.9 \%$ & 25 & $80.6 \%$ & 53 & $61.6 \%$ & \\
\hline & Only weekend & 16 & $29.1 \%$ & 2 & $6.5 \%$ & 18 & $20.9 \%$ & \\
\hline \multirow[t]{3}{*}{ Number of hour/day sport } & $<1$ & 5 & $9.1 \%$ & 1 & $3.2 \%$ & 6 & $7.0 \%$ & $0.039 *$ \\
\hline & 1 & 42 & $76.4 \%$ & 30 & $96.8 \%$ & 72 & $83.7 \%$ & \\
\hline & 2 & 8 & $14.5 \%$ & 0 & $0.0 \%$ & 8 & $9.3 \%$ & \\
\hline \multirow[t]{2}{*}{ Smoke } & Yes & 68 & $48.9 \%$ & 28 & $43.1 \%$ & 96 & $47.1 \%$ & 0.436 \\
\hline & No & 71 & $51.1 \%$ & 37 & $56.9 \%$ & 108 & $52.9 \%$ & \\
\hline \multirow[t]{5}{*}{ Number of cigarettes/day } & $<5$ & 2 & $2.9 \%$ & 5 & $17.2 \%$ & 7 & $7.2 \%$ & $0.001 *$ \\
\hline & $5-9$ & 8 & $11.8 \%$ & 13 & $44.8 \%$ & 21 & $21.6 \%$ & \\
\hline & $10-14$ & 38 & $55.9 \%$ & 7 & $24.1 \%$ & 45 & $46.4 \%$ & \\
\hline & $15-19$ & 17 & $25.0 \%$ & 3 & $10.3 \%$ & 20 & $20.6 \%$ & \\
\hline & $>20$ & 3 & $4.4 \%$ & 1 & $3.4 \%$ & 4 & $4.1 \%$ & \\
\hline
\end{tabular}

* Significant at $p<0.05$.

reported their health as "very good". In addition, two other questions were asked to blood donors regarding the number of days in which they did not feel well for mental and/or psychological reasons and the number of days in which they had limitations in the usual activities. Most participants (93.7\%) answered that they didn't feel bad in the last month for mental or psychological reasons against $6.3 \%$ who felt sick in a range of 1-6 days. Finally, the self-perceived well-being by blood donors has been correlated to some aspects (sex, education level, working situation, sport, smoke, BMI) through a multiple logistic regression. No variable examined is related to perceived wellbeing (data not shown).

\section{Discussion}

The major finding of the present study is a significant higher incidence of overweight and obesity (50.7\% and $20.0 \%)$ in males blood donors compared to women. Despite this, we observed that only $1.0 \%$ had a perception of own health state as "bad", whereas the remaining part of participants have reported to feel "good" or "very good". A major limitation the few respondents and particularly very few women in the study.

The population should be aware that balance between energy consumption and expenditure is important for health, as is the quality of nutrient intake. Different aspects of society negatively affect lifestyle as the introduction of "fast food", which led to a food style characterized by very generous portions (super-sizing) and low nutritional value or the consumption of highly energetic food (high calorie or high sodium content) and sugary drinks (highly sugary or alcoholic). ${ }^{21-23}$ This type of malnutrition induces changes in the intestinal microbiota causing dysbiosis with a probable translocation of bacteria and/or factors derived from the intestine to the liver. ${ }^{24}$

In Italy, guidelines recommend a balanced healthy diet in which the daily calories obtained should be: $55-60 \%$ from carbohydrates, of which $<10 \%$ mono- and disaccharides, $28-30 \%$ from fat, limiting saturated and preferring polyunsaturated fats as Omega- 3 and Omega- 6 , $10-12 \%$ from proteins, preferring vegetable, and $30 \mathrm{~g} /$ day of fiber [http://nut.entecra.it/]. In particular, the daily calories must be introduced for $40 \%$ at lunch, $30 \%$ at dinner, $20 \%$ at breakfast, $5 \%$ at midmorning and $5 \%$ at mid-afternoon. A balanced and equilibrate nutrition should provide a moderate intake of salt, an adequate consumption of vegetables, fruit and legumes. The Mediterranean diet is a nutritional model of a balanced nutrient intake. ${ }^{25}$ Probably, thanks to the harmonic combination of many elements with antioxidant and anti-inflammatory properties, which enrich every single nutrient or food, the Mediterranean diet represents the gold standard in preventive medicine. $^{26,27}$ The result of this diet is a significant reduction of many metabolic risk factors: reduction of triglycerides, resistance to insulin, abdominal circumference and, adiposity, improvement of endothelial function, fasting glucose and cholesterol values HDL. ${ }^{26,27}$ A recent study conducted on the populations that traditionally follow the 
Table 2

Nutritional habits and lifestyle of blood donors.

\begin{tabular}{|c|c|c|c|c|c|c|c|c|}
\hline \multirow[t]{2}{*}{ Items } & \multirow[t]{2}{*}{ Answers } & \multicolumn{2}{|c|}{ Male } & \multicolumn{2}{|c|}{ Female } & \multicolumn{2}{|c|}{ Total } & \multirow[t]{2}{*}{ p-value } \\
\hline & & $\mathrm{n}$ & $\%$ & $\mathrm{n}$ & $\%$ & $\mathrm{n}$ & $\%$ & \\
\hline \multirow[t]{2}{*}{ Diet } & Yes & 10 & $7.1 \%$ & 8 & $12.3 \%$ & 18 & $8.8 \%$ & 0.224 \\
\hline & No & 130 & $92.9 \%$ & 57 & $87.7 \%$ & 187 & $91.2 \%$ & \\
\hline \multirow[t]{5}{*}{ Type of diet } & Mediterranean & 129 & $92.1 \%$ & 56 & $86.2 \%$ & 185 & $90.7 \%$ & 0.222 \\
\hline & Vegan & 4 & $2.8 \%$ & 3 & $4.6 \%$ & 7 & $3.4 \%$ & \\
\hline & Vegetarian & 5 & $3.6 \%$ & 5 & $7.7 \%$ & 10 & $4.9 \%$ & \\
\hline & Gluten-free & 0 & $0.0 \%$ & 1 & $1.5 \%$ & 1 & $0.5 \%$ & \\
\hline & Low carb & 2 & $1.4 \%$ & 0 & $0.0 \%$ & 2 & $1.0 \%$ & \\
\hline \multirow[t]{2}{*}{ Food intolerance } & Yes & 3 & $2.1 \%$ & 1 & $1.5 \%$ & 4 & $2.0 \%$ & 0.771 \\
\hline & No & 137 & $97.9 \%$ & 64 & $98.5 \%$ & 201 & $98.0 \%$ & \\
\hline \multirow[t]{4}{*}{ Breakfast place } & Home & 85 & $60.7 \%$ & 57 & $87.7 \%$ & 142 & $69.3 \%$ & $0.001 *$ \\
\hline & Bar & 38 & $27.1 \%$ & 7 & $10.8 \%$ & 45 & $22.0 \%$ & \\
\hline & Work & 11 & $7.9 \%$ & 1 & $1.5 \%$ & 12 & $5.9 \%$ & \\
\hline & Without breakfast & 6 & $4.3 \%$ & 0 & $0.0 \%$ & 6 & $2.9 \%$ & \\
\hline \multirow[t]{4}{*}{ Breakfast type } & Abundant & 48 & $35.8 \%$ & 9 & $13.8 \%$ & 57 & $28.6 \%$ & $0.004 *$ \\
\hline & Light & 57 & $42.5 \%$ & 44 & $67.7 \%$ & 101 & $50.8 \%$ & \\
\hline & Only snacks & 1 & $0.7 \%$ & 0 & $0.0 \%$ & 1 & $0.5 \%$ & \\
\hline & Only drinks & 28 & $20.9 \%$ & 12 & $18.5 \%$ & 40 & $20.1 \%$ & \\
\hline \multirow[t]{2}{*}{ Morning snack } & Yes & 54 & $38.6 \%$ & 43 & $66.2 \%$ & 97 & $47.3 \%$ & $0.001 *$ \\
\hline & No & 86 & $61.4 \%$ & 22 & $33.8 \%$ & 108 & $52.7 \%$ & \\
\hline \multirow[t]{4}{*}{ Type of morning snack } & Drink & 16 & $29.6 \%$ & 1 & $2.3 \%$ & 17 & $17.5 \%$ & $0.001 *$ \\
\hline & Snack & 12 & $22.2 \%$ & 6 & $14.0 \%$ & 18 & $18.6 \%$ & \\
\hline & Sandwiches/pizza & 7 & $13.0 \%$ & 4 & $9.3 \%$ & 11 & $11.3 \%$ & \\
\hline & Yogurt/fruit & 19 & $35.2 \%$ & 32 & $74.4 \%$ & 51 & $52.6 \%$ & \\
\hline \multirow[t]{4}{*}{ Lunch place } & Home & 46 & $32.9 \%$ & 35 & $53.8 \%$ & 81 & $39.5 \%$ & $0.027^{*}$ \\
\hline & Bar/restaurant & 28 & $20.0 \%$ & 7 & $10.8 \%$ & 35 & $17.1 \%$ & \\
\hline & Work & 59 & $42.1 \%$ & 19 & $29.2 \%$ & 78 & $38.0 \%$ & \\
\hline & Without lunch & 7 & $5.0 \%$ & 4 & $6.2 \%$ & 11 & $5.4 \%$ & \\
\hline \multirow[t]{4}{*}{ Lunch type } & Complete meal & 28 & $21.2 \%$ & 9 & $14.5 \%$ & 37 & $19.1 \%$ & $0.026^{*}$ \\
\hline & Pasta & 28 & $21.2 \%$ & 19 & $30.6 \%$ & 47 & $24.2 \%$ & \\
\hline & Second & 17 & $12.9 \%$ & 16 & $25.8 \%$ & 33 & $17.0 \%$ & \\
\hline & Vegetables & 59 & $44.7 \%$ & 18 & $29.0 \%$ & 77 & $39.7 \%$ & \\
\hline \multirow[t]{2}{*}{ Afternoon snack } & Yes & 25 & $17.9 \%$ & 38 & $58.5 \%$ & 63 & $30.7 \%$ & $0.001 *$ \\
\hline & No & 115 & $82.1 \%$ & 27 & $41.5 \%$ & 142 & $69.3 \%$ & \\
\hline \multirow[t]{4}{*}{ Type of afternoon snack } & Drink & 10 & $40.0 \%$ & 1 & $2.6 \%$ & 11 & $17.5 \%$ & $0.001 *$ \\
\hline & Snack & 4 & $16.0 \%$ & 3 & $7.9 \%$ & 7 & $11.1 \%$ & \\
\hline & Sandwiches/pizza & 0 & $0.0 \%$ & 1 & $2.6 \%$ & 1 & $1.6 \%$ & \\
\hline & Yogurt/fruit & 11 & $44.0 \%$ & 33 & $86.8 \%$ & 44 & $69.8 \%$ & \\
\hline \multirow[t]{5}{*}{ Dinner } & Complete meal & 45 & $32.1 \%$ & 4 & $6.2 \%$ & 49 & $23.9 \%$ & $0.002 *$ \\
\hline & Pasta & 2 & $1.4 \%$ & 1 & $1.5 \%$ & 3 & $1.5 \%$ & \\
\hline & Second & 91 & $65.0 \%$ & 59 & $90.8 \%$ & 150 & $73.2 \%$ & \\
\hline & Vegetables & 1 & $0.7 \%$ & 1 & $1.5 \%$ & 2 & $1.0 \%$ & \\
\hline & Pizza/sandwiches & 1 & $0.7 \%$ & 0 & $0.0 \%$ & 1 & $0.5 \%$ & \\
\hline \multirow[t]{3}{*}{ Drinking water (liter/die) } & 0.5 & 11 & $7.9 \%$ & 4 & $6.2 \%$ & 15 & $7.3 \%$ & $0.001 *$ \\
\hline & 1 & 103 & $73.6 \%$ & 26 & $40.0 \%$ & 129 & $62.9 \%$ & \\
\hline & $>2$ & 26 & $18.6 \%$ & 35 & $53.8 \%$ & 61 & $29.8 \%$ & \\
\hline Alcohol consumption & Yes & 55 & $39.3 \%$ & 14 & $21.9 \%$ & 69 & $33.8 \%$ & $0.015^{*}$ \\
\hline & No & 85 & $60.7 \%$ & 50 & $78.1 \%$ & 135 & $66.2 \%$ & \\
\hline Alcohol type & Beer & 26 & $47.3 \%$ & 7 & $46.7 \%$ & 33 & $47.1 \%$ & 0.866 \\
\hline & Wine & 28 & $50.9 \%$ & 8 & $53.3 \%$ & 36 & $51.4 \%$ & \\
\hline & Spirit & 1 & $1.8 \%$ & 0 & $0.0 \%$ & 1 & $1.4 \%$ & \\
\hline
\end{tabular}

* Significant at $p<0.05$.

\section{BMI}

-MEN $\square$ WOMEN

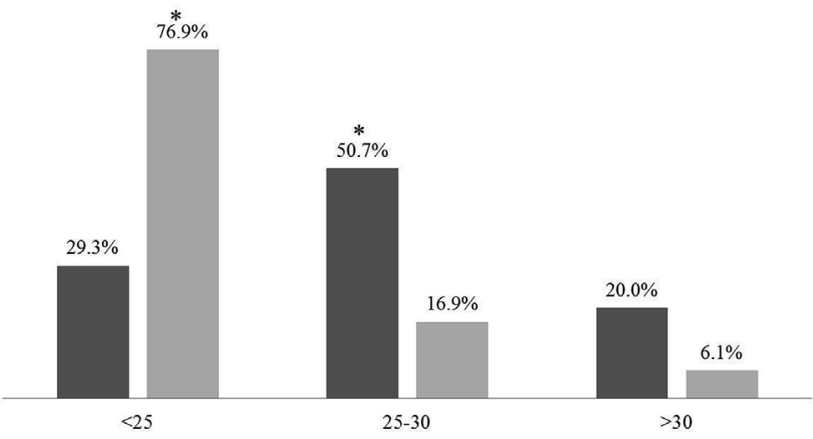

Fig. 2. Distribution of BMI in men and women. *Significant at $p<0.001$.
Mediterranean diet (such as Greek, Italian, French and Spanish) shows a significant reduction in both total and cardiovascular mortality and a protection against the physiological decline in cognitive skills. ${ }^{28}$

Although most of the interviewees in our study could distinguish the influence of healthy and unhealthy habits on their lives, it seemed to not positively impact on their weight. It also has shown their high interest on eating habits and most of the respondents were non-smokers and usual non-alcohol drinkers. Most of women had normal weight, probably as consequence of major attention to lifestyle, practicing sport and not smoking. In addition, sedentary life, working situation, lack of interest on physical activities (particularly regular exercise and healthy walk) play a crucial role in the BMI differences observed between men and women.

Sedentary behavior and the excessive time in front of the television are harmful habits that influence adults and children. ${ }^{29,30}$ Besides, 17 million annual deaths from cardio- and cerebrovascular worldwide 
Table 3

Perception of own health state.

\begin{tabular}{|c|c|c|c|c|c|c|c|c|}
\hline \multirow[t]{2}{*}{ Items } & \multirow[t]{2}{*}{ Answers } & \multicolumn{2}{|l|}{ Male } & \multicolumn{2}{|c|}{ Female } & \multicolumn{2}{|c|}{ Total } & \multirow[t]{2}{*}{ p-value } \\
\hline & & $\mathrm{n}$ & $\%$ & $\mathrm{n}$ & $\%$ & $\mathrm{n}$ & $\%$ & \\
\hline \multirow[t]{3}{*}{ Perception of own health state } & Good & 121 & $86.4 \%$ & 52 & $80.0 \%$ & 173 & $84.4 \%$ & 0.477 \\
\hline & Very good & 18 & $12.9 \%$ & 12 & $18.5 \%$ & 30 & $14.6 \%$ & \\
\hline & Not good & 1 & $0.7 \%$ & 1 & $1.5 \%$ & 2 & $1.0 \%$ & \\
\hline \multirow[t]{2}{*}{ Number of days with limitation due to physical reasons } & 0 & 121 & $86.4 \%$ & 53 & $81.5 \%$ & 174 & $84.9 \%$ & 0.363 \\
\hline & $1-6$ & 19 & $13.6 \%$ & 12 & $18.5 \%$ & 31 & $15.1 \%$ & \\
\hline \multirow[t]{2}{*}{ Number of days with limitation due to mental reasons } & 0 & 131 & $93.6 \%$ & 61 & $93.8 \%$ & 192 & $93.7 \%$ & 0.940 \\
\hline & $1-6$ & 9 & $6.4 \%$ & 4 & $6.2 \%$ & 13 & $6.3 \%$ & \\
\hline \multirow[t]{2}{*}{ Number of days with limits in usual activities } & 0 & 130 & $92.9 \%$ & 63 & $96.9 \%$ & 193 & $94.1 \%$ & 0.249 \\
\hline & $1-6$ & 10 & $7.1 \%$ & 2 & $3.1 \%$ & 12 & $5.9 \%$ & \\
\hline
\end{tabular}

* Significant at $p<0.05$.

accidents are caused by improper nutrition and sedentary lifestyle. ${ }^{31,32}$ Physical activity, the relation with the environment, diet, and other aspects of daily life play a crucial role in physical and mental health. An effective indicator of overall health status and a useful tool to inform about the care needs is self-perceived health status. ${ }^{33}$ However, there are only few studies on the association of psychological well-being to nutritional status. In Italy, from a survey on how the population judges own state of health emerged 7 out of 10 people considered their state of health "positive" (declaring they feel good/very good) (Passi data from 2014 to 2017). Approximately 3\% of the population reported that they feeling bad/very bad; the remaining part declared to feel "good". It has been noted that young people, men, people with a higher socio-economic level, for education or economic conditions, foreign citizens other than Italians and those who are free from severe pathological conditions are more satisfied with their health.

It has been demonstrated that weight misperceptions defined as discrepancies between objective indicators of weight and individuals' perceptions of their weight status appear common in the population. $^{34,35}$ Recently researchers have expressed concerns that obeses underestimate their weight lacking motivation to engage health behavioral changes (despite to achieve misperceptions of being overweight in the eating disorder). ${ }^{35,36}$ According to these data, we noted a percentage of $37.07 \%$ normal weight, $34.15 \%$ overweight and $13.17 \%$ obese blood donors that feel good (data not shown).

Finally, blood centers can play a public health role in overweight and obesity surveillance but we are not aware of published data on BMI distributions among blood donors in the whole region.

This demographic study has some limitations based on the small number of recruited blood donors and the characteristics of the participants. Data may not be comparable to national statistics due to the nature of the study design. Furthermore, results may not be transferable to other populations. No information on portion sizes of food frequency items was obtained, nor was it possible to adjust scores by energy intake. Besides, there was limited dietary information on unsaturated fats and meat alternatives, e.g., nuts, seeds, beans/legumes, tofu, or eggs.

\section{Conclusion}

This demographic study has provided an understanding of health knowledge and attitude of the blood donors that might affect their health and life expectancy. Our initial idea was that regular blood donors would be more attentive to lifestyle and nutritional habits, but our results showed exactly the contrary. In particular, males are prevalently overweight or obese showing that they do not eat a balanced healthy nutrition. The collected data showed that included women have a better knowledge of the nutritional properties of food and consequently adopt a more balanced and proper diet. Furthermore, it is clear that they are well aware about the relationship between lifestyle and health putting into practice their information. Moreover female donors pay more attention to eating behavior and physical exercise. Unfortunately, the survey structure, of observational nature, does not make it possible to establish whether women are more alert to health to participate more in donation programs or if, on the contrary, the status of regular donor could help the improvement of knowledge and healthy lifestyle.

\section{Declaration of competing interest}

The authors declare that they have no conflict of interest.

\section{References}

1. Peckmezian T, Hay P. A systematic review and narrative synthesis of interventions for uncomplicated obesity: weight loss, well-being and impact on eating disorders. $J$ Eat Disord. 2017;5:15. https://doi.org/10.1186/s40337-017-0143-5.

2. Frongillo EA, Nguyen HT, Smith MD, Coleman-Jensen A. Food insecurity is associated with subjective well-being among individuals from 138 countries in the 2014 gallup world poll. $J$ Nutr. 2017;147:680-687. https://doi.org/10.3945/jn.116. 243642 .

3. Schnettler B, Lobos G, Lapo MD, Adasme-Berríos C, Hueche C. Satisfaction with life and food-related life in Ecuadorian older adults. Nutr Hosp. 2017;34:65-72. https:// doi.org/10.20960/nh.977.

4. Thompson FE, Midthune D, Subar AF, Kipnis V, Kahle LL, Schatzkin A. Development and evaluation of a short instrument to estimate usual dietary intake of percentage energy from fat. $J$ Am Diet Assoc. 2007;107:760-767 PMID: 17467371.

5. Nelson MC, Lytle LA. Development and evaluation of a brief screener to estimate fastfood and beverage consumption among adolescents. J Am Diet Assoc. 2009;109:730-734. https://doi.org/10.1016/j.jada.2008.12.027.

6. Shim JS, Oh K, Kim HC. Dietary assessment methods in epidemiologic studies. Epidemiol Health. 2014;36. https://doi.org/10.4178/epih/e2014009 e2014009.

7. Font-Burgada J, Sun B, Karin M. Obesity and cancer: the oil that feeds the flame. Cell Metabol. 2016;23(1):48-62. https://doi.org/10.1016/j.cmet.2015.12.015.

8. Egger G, Dixon J. Beyond obesity and lifestyle: a review of 21 st century chronic disease determinants. BioMed Res Int. 2014;2014:731685. https://doi.org/10.1155/ 2014/731685.

9. Bauer UE, Briss PA, Goodman RA, Bowman BA. Prevention of chronic disease in the 21st century: elimination of the leading preventable causes of premature death and disability in the USA. Lancet. 2014;384(9937):45-52.

10. Fardet A, Boirie Y. Associations between food and beverage groups and major dietrelated chronic diseases: an exhaustive review of pooled/meta-analyses and systematic reviews. Nutr Rev. 2014;72(12):741-762. https://doi.org/10.1111/nure. 12153.

11. Lifshitz F, Lifshitz JZ. Globesity: the root causes of the obesity epidemic in the USA and now worldwide. Pediatr Endocrinol Rev. 2014;12:17-34 PMID: 25345082.

12. Wilson SL, Gallivan A, Kratzke C, Amatya A. Nutritional status and socio-ecological factors associated with overweight/obesity at a rural-serving US-Mexico border university. Rural Remote Health. 2012;12:2228 PMID: 23176343.

13. Binkin N, Fontana G, Lamberti A, et al. A national survey of the prevalence of childhood overweight and obesity in Italy. Obes Rev. 2010;11:2-10. https://doi.org/ 10.1111/j.1467-789X.2009.00650.x.

14. Owen L, Corfe B. The role of diet and nutrition on mental health and wellbeing. Proc Nutr Soc. 2017;76:425-426. https://doi.org/10.1017/S0029665117001057.

15. Condello G, Capranica L, Stager J, et al. Physical activity and health perception in aging: do body mass and satisfaction matter? A three-path mediated link. PloS One. 2016;11. https://doi.org/10.1371/journal.pone.0160805 e0160805.

16. Diener E, Pressman SD, Hunter J, Delgadillo-Chase D. If, why, and when subjective well-being influences health, and future needed research. Appl Psychol Health Well Being. 2017;9:133-167. https://doi.org/10.1111/aphw.12090.

17. Belsito A, Costa D, Fiorito C, et al. Erythrocyte genotyping for transfusion-dependent patients at the Azienda Universitaria policlinico of Naples. Transfus Apher Sci. 2015;52:72-77. https://doi.org/10.1016/j.transci.2014.12.006.

18. Sommese L, Sabia C, Esposito A, Iannone C, Montesano ML, Napoli C. Comparison of performance of two Treponema pallidum automated chemiluminescent 
immunoassays in blood donors. Infect Dis (Lond). 2016;48(6):483-487. https://doi. org $/ 10.3109 / 23744235.2016 .1142674$.

19. Belsito A, Costa D, Signoriello S, et al. Clinical outcome of transfusions with extended red blood cell matching in $\beta$-thalassemia patients: a single-center experience. Transfus Apher Sci. 2019;58(1):65-71. https://doi.org/10.1016/j.transci.2018.11. 006.

20. Rigas AS, Sørensen CJ, Pedersen OB, et al. Predictors of iron levels in 14,737 Danish blood donors: results from the Danish Blood Donor Study. Transfusion. 2014;54:789-796. https://doi.org/10.1111/trf.12518.

21. Rehm CD, Drewnowski A. Trends in consumption of solid fats, added sugars, sodium, sugar-sweetened beverages, and fruit from fast food restaurants and by fast food restaurant type among US children, 2003-2010. Nutrients. 2016;8 E804. PMID: 27983573.

22. Ravensbergen EA, Waterlander WE, Kroeze W, Steenhuis IH. Healthy or Unhealthy on Sale? A cross-sectional study on the proportion of healthy and unhealthy foods promoted through flyer advertising by supermarkets in The Netherlands. BMC Publ Health. 2015;15:470. https://doi.org/10.1186/s12889-015-1748-8.

23. Powell LM, Nguyen BT. Fast-food and full-service restaurant consumption among children and adolescents: effect on energy, beverage, and nutrient intake. JAMA Pediatr. 2013;167:14-20. https://doi.org/10.1001/jamapediatrics.2013.417.

24. Vasco M, Paolillo R, Schiano C, Sommese L, Cuomo O, Napoli C. Compromised nutritional status in patients with end-stage liver disease: role of gut microbiota. Hepatobiliary Pancreat Dis Int. 2018;17:290-300. https://doi.org/10.1016/j.hbpd. 2018.06.004.

25. Veronese N, Stubbs B, Noale M, Solmi M, Luchini C, Maggi S. Adherence to the Mediterranean diet is associated with better quality of life: data from the Osteoarthritis Initiative. Am J Clin Nutr. 2016;104:1403-1409 PMID: 27680996.

26. Garcia M, Bihuniak JD, Shook J, Kenny A, Kerstetter J, Huedo-Medina TB. The effect of the traditional mediterranean-style diet on metabolic risk factors: a meta-analysis. Nutrients. 2016;8:168. https://doi.org/10.3390/nu8030168.

27. Martínez-González MA, Sánchez-Villegas A. The emerging role of Mediterranean diets in cardiovascular epidemiology: monounsaturated fats, olive oil, red wine or the whole pattern? Eur J Epidemiol. 2004;19:9-13 PMID: 15012018.

28. Papadaki A, Johnson L, Toumpakari Z, et al. Validation of the English version of the 14-item mediterranean diet adherence screener of the PREDIMED study, in people at high cardiovascular risk in the UK. Nutrients. 2018;10(2) https://doi.org/10.3390/ nu10020138 E138.

29. Rosiek A, Maciejewska NF, Leksowski K, Rosiek-Kryszewska A, Leksowski Ł. Effect of television on obesity and excess of weight and consequences of health. Int $J$ Environ Res Publ Health. 2015;12:9408-9426. https://doi.org/10.3390/ijerph120809408.

30. Mielke GI, da Silva IC, Owen N, Hallal PC. Brazilian adults' sedentary behaviors by life domain: population-based study. PloS One. 2014;9. https://doi.org/10.1371/ journal.pone.0091614 e91614.

31. Li J, Yu J, Chen X, Quan X, Zhou L. Correlations between health-promoting lifestyle and health-related quality of life among elderly people with hypertension in Hengyang, Hunan, China. Medicine. (Baltimore). 2018;97(25) https://doi.org/10. 1097/MD.0000000000010937 e10937.

32. Castro I, Waclawovsky G, Marcadenti A. Nutrition and physical activity on hypertension: implication of current evidence and guidelines. Curr Hypertens Rev. 2015;11:91-99 PMID: 25921545.

33. Steptoe A, Deaton A, Stone AA. Subjective wellbeing, health, and ageing. Lancet. 2015;385:640-648. https://doi.org/10.1016/S0140-6736(13)61489-0.

34. Patte KA, Laxer R, Qian W, Leatherdale ST. A cross-sectional analysis of weight perception and weight-control intentions among secondary school students in the COMPASS study. Am J Health Behav. 2016;40:614-623. https://doi.org/10.5993/ AJHB.40.5.8.

35. Jackson SE, Johnson F, Crocker H, Wardle J. Weight perceptions in a population sample of English adolescents: cause for celebration or concern? Int $J$ Obes (Lond). 2015;39:1488-1493. https://doi.org/10.1038/ijo.2015.126.

36. Deschamps V, Salanave B, Chan-Chee C, Vernay M, Castetbon K. Bodyweight perception and related preoccupations in a large national sample of adolescents. Pediatr Obes. 2015;10:15-22. https://doi.org/10.1111/j.2047-6310.2013.00211.x. 